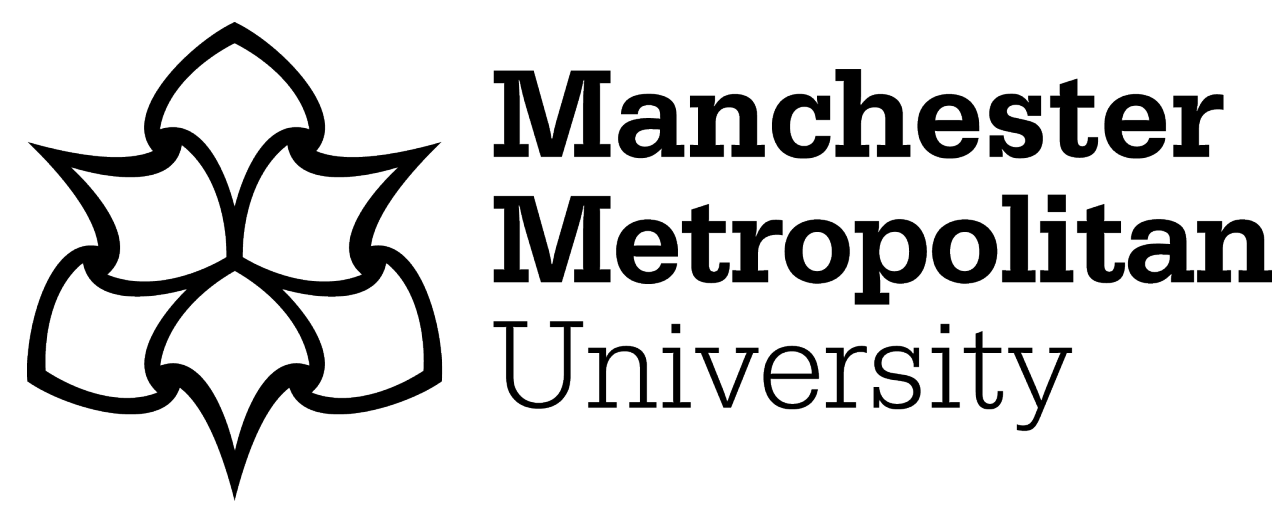

Choi, Youngok, Na, Jea Hoo, Walters, Andrew, Lam, Busayawan, Boult, John, Jordan, Patrick W and Green, Stephen (2018) Design for social value: using design to improve the impact of CSR. Journal of Design Research, 16 (2). pp. 155-174. ISSN 1569-1551

Downloaded from: https://e-space.mmu.ac.uk/622406/

Publisher: Inderscience

DOI: https://doi.org/10.1504/jdr.2018.092818

Please cite the published version 


\title{
Design for Social Value: Using design to improve the impact of CSR
}

\begin{abstract}
This paper discusses the meaning of social value from the design perspective, especially in Corporate Social Responsibility practices, and the contextual issues and values derived from design, considering how companies could better use design for social value creation. The research identified consumer attitudes to corporate social value and where companies are perceived to have generated social value, and explored where design has contributed to such social value. The research illustrates that design has great potential to add value to the triple bottom line, mostly related directly to organisations, but also to areas relating to society, including the 'lower levels of environmental degradation' and 'more solutions for social issues', indicating design plays an influential role in creating socially responsible products/services. However, this research suggests that a clear definition of 'social value' from various perspectives and its relationship with CSR is required due to the complex and subjective nature of 'social value'.
\end{abstract}

Keywords Design, Design Value, Social Value, Social Value of Design, Design Impact, CSR practices

\section{Introduction}

Many businesses nowadays actively promote their Corporate Social Responsibility (CSR) programmes because they are aware of its importance and impact. CSR is widely regarded as a self-regulation mechanism, which enables businesses to identify their impact on society and ensure they comply with social standards. The social responsibilities, therefore, can range from socio-economic factors such as provision of jobs in local community and better treatment for the employees, to environmental factors such as reducing the Carbon Footprint (International Organisation for Standardisation [ISO], 2010). CSR is widely regarded as a self-regulation mechanism, which enables businesses to identify their impact on society and ensure they comply with social standards (e.g. human rights) and is also seen as an important competitive advantage which encourages product/service/brand uptake on aspects beyond functionality and price sensitivity (Collings, 2010). The majority of the FTSE100 and two-thirds of the FTSE's Global 100 now produce CSR reports, although most CSR practices described in these reports 
focus on charitable activities rather than delivering responsible products/services (Rare Corporate Design, 2011). Gates (2008) suggests that CSR practices can be integral to every business activity, and many business frameworks - e.g. the Seven Social Wins of Brand (Hilton, 2003) and CSR in the framework of quality management (Frolova and Lapina, 2014) - support this idea. CSR also contributes to a broad range of social and ethical issues which are relevant to community, diversity, human rights and corporate governance (Polosnsky and Jevons, 2006).

Design is increasingly recognised as an integral part of sustainable development for its potential to make significant contributions to society: leading social change, realising social values and influencing customer experience (Chen et al., 2015). A comprehensive review of CSR reports, however, indicates that design has been barely perceived as a strategic tool for addressing CSR issues and delivering social values through products/services. Design is often used for one-off social innovation showcases and thus its social return is implicitly recognised rather than quantified. Perhaps the potential underutilisation of design is partly due to a lack of understanding of the impact of design in creating social value and companies' limited CSR practices. Here the research seeks to explore how can design be used to create social value whilst supporting more integrated CSR practices to benefit society, users and businesses? - an important and timely question as a company's social responsibility is an increasingly important factor in customer purchase decision-making (Nielsen, 2014).

This paper discusses the result of an exploratory AHRC-funded research project with various stakeholders, including design and brand professionals and design support organisations: The Design Council, British Industrial Design Association (BIDA), Design Management Europe (DME), and various businesses. The research aimed to identify the meaning of social value, especially in CSR practices, and to explore the contextual issues and value of design in creating social impact of CSR.

\section{Literature Review of Social Value, CSR and Social Design}

The literature review was conducted to understand the research context: the meaning of social value, CSR practice and design and social value. This section presents the key findings of the literature review on which the theoretical background of this research is based.

\subsection{Social Value}


Zeithaml (1988), an early scholar who described value from a commercial/consumer perspective, asserted that value is the overall appreciation of products or services, for which customers make appropriate payment. Several interpretations followed Zeithaml's descriptions, as demonstrated in the literature research by Paananen and Seppänen (2013), but it can be broadly divided into emotional, social, and functional value (Sweeney and Soutar, 2001). In a more consumer-focused research, the value is described as having influence on the acceptance, adoption and diffusion of Product Service Systems (Piscicelli et al., 2015). Hunter (2014) focuses on social value, describing it as something which social enterprises and organisations give back, where success is not merely defined as 'shipping a lot of units' but trying to understand whether they have improved life, made no impact, or made matters worse. In a commercial environment, social value is therefore more elusive than economic value as there is no objective means to measure its outcome. Furthermore, social value is hard to define because it is intrinsically highly subjective and complex, making it difficult to construct a comprehensive framework in which to firmly identify and measure social value outcomes. There are thus various interpretations of the parameters of the social value of businesses; McElroy (2002) describes the relationship or interaction of a community's individuals both in and between firms - with a greater focus on the corporate environment - whereas Elkington (2004) and International Organisation for Standardisation (ISO, 2010) expand the reach to include an organisation's environmental and societal impact, which will be explored further in the next section. This research adopts the wider parameters of social value and combines the fundamental theory of the value, as described earlier. The working definition of social value for this research is therefore defined as "financial/emotional appreciation by the users or potential users of products/services/brands (PSB), which address social issues for the individual, company, community and/or environment in order to create a good society whilst meeting the needs of an organisation."

Since social value is often seen as a separate entity to economic value, it is sometimes hard to convince the commercial sector that social values should be an important strategic aspect of business success. In contrast, NGOs emphasise this much more clearly, with social value parameters which are more easily identified than those of businesses because their work focuses on creating a particular area(s) of social value. Nevertheless, the trend is growing for businesses to consider the social implications of their product, service and brand in response to consumer demand, where the consumers have complex decision-making processes and purchasing habits. Nielsen (2014) describes social value creation as a competitive business 
advantage because over half of global consumers would willingly pay more for goods and services from companies committed to being socially responsible.

\subsection{CSR Practice}

Corporate responsibility comprises two aspects (Hazarika, 2013): firstly, a company's integral responsibility towards its primary stakeholders including employees, customers, investors and suppliers, and secondly the company's increased social improvements, which has evolved from philanthropic practice, also referred to as CSR. A PricewaterhouseCooper (2002) study of why companies strive to be more socially responsible revealed (i) enhanced reputation, (ii) competitive advantage, (iii) cost savings, (iv) industry trends, (v) CEO/board commitment, (vi) customer demand, (vii) Socially Responsible Investment (SRI) demand, (viii) top-line growth, (ix) shareholder demand, and (x) access to capital. As the advantages to companies of adopting CSR become more apparent, the boundaries between social and commercial enterprises are becoming more blurred (Hebbar, 2010). This blurring of the business motive could be regarded as a means to achieving increased social value creation for companies. However, the transformation must be approached cautiously and strategically because if CSR is considered generically rather than in line with the company's strategy, it can be counterproductive for the business (Potter and Kramer, 2006). The 'Six major initiatives and descriptions of Corporate Social Initiatives' suggested by Kotler and Lee (2005) advise companies to build themselves as a 'social brand' if they aspire to promoting themselves through social issues. Cook also emphasises this, identifying the key contributors to making a successful 'social brand' as (i) popularity, (ii) receptiveness, (iii) interaction, (iv) network reach, and (v) trust (Cook, 2011). These contributors are all generically customer-focused factors and to improve these aspects, Product, Service and/or Brand (PSB) design can be important, as design is also intrinsically 'customer-centric'. A company's commitment to CSR will vary greatly depending on its circumstances. However, Ernst and Young's research suggests that top management's ability to take charge and show leadership in CSR initiatives still remains the primary driver for successful CSR practice (EY, 2013).

The Committee for Economic Development (CED) posited three circles - inner, intermediate and outer - in which a corporation places itself. The circles can be seen as levels of CSR: the inner circle (level one) contributes to socio-economic function as a corporation; the intermediate circle (level two) is where the company is responsible for the welfare and fair treatment of the people and environment connected to the corporation; the outer circle (level three) is for a corporation which actively extends its reach to wider areas, with a strong 
emphasis on social impact (CED, 1971). Figure 1 represents the CED's theory of CSR. This was an early implementation of social issues within the realm of corporate responsibilities. The fundamentals of the CED's theory has withstood the test of time, and its implementation has subsequently been more widely discussed. CSR began to appear in the strategy literatures in the 1990s, and by the 2000s it had become an important issue in many companies (Moura-Leite and Padgett, 2011). The ISO 26000:2010 adopted a similar approach to that of the CED, placing importance in the impact of organisations' decisions and subsequent actions on society and the environment (ISO, 2010).

Figure 1 Theoretical CSR levels for companies (Adapted from CED, 1971)

In conjunction with these CSR working areas, Matten and Moon's theory of implicit and explicit CSR further explains the meaning of CSR to businesses (Matten and Moon, 2008). An important difference between the two categories of CSR is 'intent'. Explicit CSR is deliberate, voluntary and strategic - actively led by the company - whereas companies with implicit CSR may have the same practices as companies with explicit CSR, but are often not a deliberate corporate decision, rather a reaction to the company's social and economic environment passively followed by the company. Although social responsibility activities are intended to benefit society, the research identified critical issues about defining a social value element, ranging from the difficulty of trusting a corporation - regarded as a profit-driven organisation - to the intrinsic meaning and value of CSR.

\subsection{Design and Social Value}

The importance of the social value of design increases as design's expanding role and influence are cultivated as the discipline matures. Although the influence of design has been mostly on the economic pillar of the triple bottom line (Elkington, 2004), design's ability to influence change in society has been discussed from Papanek's early writings in the 1960s (Papanek, 1985) and research in this area has gained momentum in the last decade (Chen et al., 2015). Joziasse and Selders (2009:31) describe how design can add value, principally relating directly to organisations but with two areas which relate to society, including the "lower levels of environmental degradation" and "more solutions for social issues (ageing, literacy, etc.)". Lockwood (2011:244) also argues that "design has more potential to lead change, enable innovation, influence customer experience and add value to the triple bottom line than any other business function." The influences of design are evident in a company's PSB where the 
designers are regarded as people who influence customers' positive or negative habits and social routines by inscribing a morality in the PSB (Jelsma, 2006; Scott et al., 2012). Furthermore, design's meaning and scope is becoming as diverse as the meaning of social value (Mozota, 2006; Na et al., 2017). It can have a specific view which describes design as part of activity, which produces goods (discipline-based design, i.e. product design, engineering design, graphic design etc.), to using design as a strategic tool to manage business more creatively - sometimes referred to as strategic design (Best, 2015; Stevens and Moultrie, 2011) or design thinking (Brown, 2009; DC, 2014; Martin, 2009). Design's social value can thus have many interpretations, especially to what extent design influences the creation of social value (Koo and Cooper, 2011). Nevertheless, many organisations have noted design's influence on creating positive social changes, so design companies are increasingly used to create social values in collaboration with NGOs and commercial companies (Smithsonian, 2013).

Figure 2 visualises an overview of this relationship, depicting the interlinking stakeholders of 'social design' and 'commercial design', and the different purpose of products/services depending on whether they were designed for society, with consideration of society - both profitable and good for society - or for profit. Products designed for profit do not necessarily lack social value - they, too, can have indirect societal/environmental benefits. The Brompton bike, for example, has contributed to making commuting by bike fashionable and more widely accessible: the product has inherent environmental benefits and personal health benefits. However, a product designed with consideration for society is likely to be of greater benefit to society and/or the environment e.g. the OXO Good Grips range's initial aim was to address the social issue of kitchen utensil usability for people affected by arthritis, yet it has achieved significant economic success and is considered comfortable to use by many users (Esslinger, 2009).

Figure 2 Overview of the relationship between design stakeholders (including social \& commercial design) and examples of products/services with social value.

\section{Methodology}

A qualitative research approach was used, as the research requires in-depth discussions and interactions with stakeholders to raise the issues and identify meaningful outcomes from the complex topic of the social value of design. The research had two phases: the first phase sought 
to understand the contextual issues of social value, CSR and the social value of design in both theoretical and practical perspectives to construct a comprehensive picture of social value. This phase comprised a literature review (academic literature, and organisational and industrial reports), Workshop One (exploratory) and Workshop Two. The second phase further investigated the elements of creating high social value and the use of design in social value creation to raise practical issues of implementing design for better social value creation in the commercial sector. This phase comprised Workshop Three (exploratory) and Workshop Four with supporting desk research to ensure a balanced view of the topic. The supporting research, including an extensive literature review, was conducted throughout the project's duration to enhance the understanding of the context and identify current theories and practices, with particular reference to the social value of design, social impact of CSR practices, the role of design in relation to social value/responsibility and the critical notion of design value. A review of journal papers, books, mass media (news and magazines) and websites of relevant organisations and blogs provided sources for the literature review. The main research areas followed the identified phases of the research project, where in the first phase keywords were 'social value', 'CSR' and 'Social Design', and the second phase keywords included 'role of design', and 'social value creation'.

The workshops were the main empirical research instruments, being appropriate to the aims because they provide an opportunity for rich exchanges of opinions from various stakeholders on the complex topic of social values and design. Exploratory Workshops One and Three were conducted with postgraduate and doctoral students in Design, Sociology, Marketing and Business, to obtain an overview of the issues and test the relevance and practicality of activities for Workshops One and Two. The participants were selected for their personal and academic interest in design, social value and CSR. Two main workshops with professional groups in design, brand, social science, marketing and businesses followed the exploratory workshops. Workshop Two had twenty-two participants (from design NGOs, trade bodies, businesses, design institutes, local communities and design/brand consultancies, including The Design Council, DME, Aalto University, Institute for Sustainable Design and Tilbury Corporation) and three activities: (i) a discussion of social value elements, to create a comprehensive map of social values, (ii) social shoppers - to understand the relationship between purchasing behaviour and the perception of companies' social engagement - and (iii) the role of design in social value creation: exploring the contribution of design in social value creation. Workshop Four's nineteen participants (from design NGOs, design and brand consultancies, businesses, local communities and design institutes including DBA, Goldman 
Sachs, DesignConnect, Saffron, Tangerine, BOP Consulting and Hayes Town Partnership) engaged in activities including mapping social values of design, and investigating elements of design influences on social value creation followed by in-depth discussion to identify the elements required to create high social values.

The workshop activities were designed to maximise participation, using relevant visual materials including example cards of 'socially responsible' products and services including OXO Good Grips, BlaBlaCar, London Cycle Hire, Nest, Colalife, Dove and Innocent Drinks, to stimulate conversation, and small groups of five or six participants for more active opinionsharing. The examples were selected through extensive desk research and further discussions of the research team (four academics, five design and branding professionals, and three researchers). The selection criteria were to be (i) easily recognisable or understandable by the participants, (ii) simple to distinguish the societal (including environmental) advantage compared with the competitors, and (iii) easily drawn out discussion of design and commercial values. Thirty-three examples were initially identified which could represent existing products, product/service systems and brand/campaign (eleven examples in each category), and four examples of each category were then finally selected and used in the workshop discussions. Each group in the workshop included two research team members to facilitate and take notes of the discussion. The facilitators were instructed to ensure the group discussions were relevant to the topic and that all group members participated. To prevent bias in the discussion, facilitators' participation in the conversations was kept to minimum. Participants were asked to write their thoughts on post-it notes, to record all the opinions discussed during activities. At the end of each activity the group presented the main points raised in the discussion, which was video-recorded to be further reviewed. The recorded materials were then analysed shortly after each workshop using content and thematic analysis methods, as described by Bryman (2016), to critically extract group opinions from the workshop, to better understand the complex topic of social values and the role of design for social value creation.

\section{Phase One Findings and Discussion: Understanding Social Value}

Phase One sought a better understanding of the contextual issues surrounding social value and CSR. This section presents the findings and discussion of the first phase of the research.

\subsection{Elements of Social Value}


The outcome of Workshop One was analysed, including the activities and discussions about social value, and the main themes of social values were identified as: (i) Individual Ethics, (ii) Company Ethics, (iii) Community Ethos and (iv) Responsibility for the Natural Environment. The description of each theme is derived from the group discussion.

- Individual Ethics (Individual): An individual sense of right or wrong: the level of ethics reflects upbringing, family values, religion, philosophy and/or personal belief. Value allows an individual to increase self-esteem or 'feel good' about him/herself (emotion);

- Company Ethics (Company): A corporate sense of right and wrong: inward values are adopted to benefit employees, whereas outward values are the actions a company takes towards 'doing a right/good thing' for people/community/ environment;

- Community Ethos (Community): A people-centred value for groups (community) a local, national and/or global community - is mostly driven by NGOs and the public sector to empower people in need, making the community a better place to live; and

- Responsibility for the Natural Environment (Earth): Caring for the Earth: preserving the planet, responsible use of natural resources, reducing waste, recycling and a circular economy all contribute to being responsible for the natural environment.

The Social Value Matrix was developed from these themes and each topic discussed in the workshop was placed back in the matrix to identify the participants' level of interest (see Figure $3)$.

Figure 3 Social Value Matrix with discussion topics and the number of subtopics (in brackets) from Workshop One.

All areas of the social value matrix are closely linked, the results showing that discussions were clustered in company ethics and community ethics. The 'output' (products/services) was the most frequently discussed company ethics topic, perhaps because it was the most visible and relevant to the participants purchasing and using products/services in everyday life. The driver (motivation) for the company ethic is mentioned less frequently than the output, perhaps indicating that for company ethics the participants are vigilant about 'what' and 'how' companies portray their ethics compared to 'why' they practice them. The second most 
discussed area was the 'driver' for the community, including 'moral code', 'connection' and 'empowerment'. In comparison to company ethics, motivation (the driver) is discussed more than the output for social ethics. The participants were least interested in the environment (Earth) category, perhaps because the term 'social' value emphasises the interaction of people and community more than the environmental aspect.

\subsection{Social Value and the Users}

While Workshop Two results revealed that social value is becoming important in customers' purchasing and decision-making, the perception of what is socially valuable can differ widely according to individual circumstances and beliefs. Some people regard considering social value a luxury, while for others it may be the most important factor in their decision-making. The workshop also identified that social values were constantly compared, and sometimes conflicted with other decision-making factors e.g. convenience and functionality. Consideration of social value was also affected by purchase frequency, peer-pressure and ownership of the product/service (see Table 1).

Table 1 Current CSR, Brand and Consumer purchasing behaviour issues identified in Workshop Two.

While several factors make understanding social value complicated, Workshop Two identified three which demanded particular attention:

- Shifting Boundaries: The social value of a product or service depends on where the boundary around its impact is drawn, e.g. an electric car may give carbon-neutral journeys at the pointise use, but its environmental impact includes how the electricity used to power it is produced. Similarly, locally-sourced produce may have fewer airmiles than those produced abroad, but may require more chemicals to help them grow outside their most efficient growing habitat.

- Narrative Integrity: The narrative accompanying a product affects people's perception of social value. People tend to believe a product or service has high social value if an attractive story is attached, e.g. the Dove 'Campaign for Real Beauty' struck a chord with many because it promotes the message that women of all shapes, sizes and 
ages are beautiful, yet the product range includes anti-wrinkle cream, suggesting that the story may not reflect the brand's real values.

- Trade-offs: Sometimes social values clash, so the overall social value of a product or service depends on how we weight the comparative importance of different values, e.g. some Fairtrade products may be associated with more air-miles, but the people involved in their production may work in good conditions and receive a fair wage, beneficial to developing world communities.

The first phase of the research provided insight into consumers' perceptions of social value and their expectations and behaviours towards commercial enterprises. Among the four key elements of social values identified in this section, the outcome of CSR activities or images (brands) portrayed by the companies are considered important in judging the level of social value. However, the outcome and image can be easily changed with many factors including shifting boundaries, narrative integrity and trade-offs. In order to increase and sustain a company's social value, therefore, multiple factors must be systematically considered, rather than a one-off philanthropic CSR activity to address a short-term issue. The next section discusses the factors for creating high social value and the impact of design on social value creation.

\section{Phase Two Findings and Discussion: The Social Value of Design}

The second phase of the research further investigated the topic of social value and its relevance in design, focusing on creating high social values for businesses.

\subsection{Design for Social Value Creation}

Both workshops in the second phase (Workshop Three and Workshop Four), reveal the perception that design can impact on creating social values for the commercial sector, e.g. visible solutions included better store design to influence customer behaviour, waste-reducing packaging design, and service design to help the customer be more socially responsible, or serve the community more effectively. It was also identified that design influences social value with many overlaps between different areas of the matrix. Design was discussed as a part of discipline (i.e. product/package/service design, etc.), as a strategic decision-making tool, and a change management tool. The groupings of PSB examples in Workshop Four (Figure 4) 
demonstrate that the influence of design on creating social value may vary dramatically depending on the perception of what design is.

Figure 4 Grouping Product example cards (left), Product/Service System example cards (centre), and Campaign/Brand Promotion example cards (right) on a matrix to determine the relationship between design and social value.

In the product examples (Figure 4, left) almost no example cards were placed in the high social value with low design input. This void shows that without design input, high social value is less likely in the 'product' category. With the 'product/service system' category (Figure 4, centre), almost all examples were placed as having high social value. This indicates that even with perceived low design input, the product/service system can have high social value, unlike the product category. The result also shows, predictably, that the service category is likely to have higher social value, as it is much easier to see how service will impact on people and society as whole. It also appears that system design is an element which may be perceived as having significant design input, e.g. Tesla and London Cycle Hire, where complex large design resources are used to create a system. This indicates that when design is seen as part of creating a service or system, design's role in social value becomes higher than if the design practice is limited to making a product aesthetically pleasing. Thus, impact for society increases when the design is fully integrated in a system which addresses the elements of creating high social values (Janzer and Weinstein, 2014). Similarly, inclusive design like OXO Good Grips showed high social value. However, the workshop results show that significant design input does not necessarily create high social value, e.g. Dyson Hot+Cold, so it is difficult to identify an emerging relationship between design input and social value.

As with the product/service system category, in the campaign category (Figure 4, right), most examples were thought to have some design input. However, even with perceived design input, there was no guarantee that it would have high social value. The Innocent brand showed low social impact despite all participant groups agreeing that it had significant design input. When first launched, the Innocent brand satisfied several elements of social value (this will be further discussed in Section 5.2): encouraging behavioural change, raising awareness and being original in making healthy drinks fashionable with a genuine brand story. However, as the market became saturated with similar products, its differentiation was dramatically reduced. Despite the campaign to help Age UK, using novelty knitted hats, it began to lose its originality, and was seen as a less impactful social campaign. 


\subsection{Creating High Social Value}

The analysis of Workshop Four discussions identified the key elements (actions) of PSB which create high social value. Existing assessment and measurement tools from both businessoriented and social impact measurement tools were used in the workshop, exploring the PSB elements, which create a high social value which appeals to consumers. Using thematic analysis, the comments were grouped according to how often each theme was mentioned (see Figure 5). The result shows that 'mass reach' is the most obvious element evident in PSB, where participants see value in helping as many people as possible. PSB should also demonstrates good understanding of culture and context, and encourage behavioural and system change for the better. This last point is important, as it can also contribute to making PSB's social initiative reach more people, and making the change last, which reflects the importance of social issues relating to 'people', reflecting the social value matrix.

Figure 5: PSB Elements (Actions) which create high social value

Workshop Four also raised the critical issue of CSR/Social value creation: whether a company is genuinely promoting social betterment through PSB or merely using it as a marketing option. This could be judged using knowledge and awareness of the PSB, and whether it is a credible reflection of the company's social intention. It is important, therefore, to have more responsible products/services with direct connections to genuine CSR activities. The social activity, whether part of product/service or as a separate activity, then has added value for the company and is intrinsic to the competitiveness of their PSB. Design has the potential to address these issues by ensuring that PSB's rooted social interest is effectively communicated. Those elements can be further developed to contribute to the measurement tool's assessment criteria to ensure that the measured value of design has an outcome, which creates high social value PSB.

\section{Conclusion}

Consumers are becoming more aware of the social implications of their purchasing behaviour and increasingly choosing to say that social values positively influence purchasing behaviours. Thus, organisations which communicate and practice effective CSR can influence/shape brand 
perception and their customers' purchasing behaviour. This research asked a question about the meaning of social value and the influence of design in creating social value to enhance the CSR practices which will benefit the society, users and businesses. The research identified four main themes of social value: individual ethics, company ethics, community ethos and responsibility for the natural environment. The themes were closely linked, but the area of company ethics was discussed more than any other areas, indicating that a company's CSR activity is of high interest in social value discussions. The research also revealed that social value is complex and subjective, variable across industries, societies and time.

The complex subjective nature of 'social value' - including varying perspectives on what is socially valuable, which inevitably change markedly according to individual circumstances and beliefs - makes it a challenge to define the term and to identify where companies should focus their efforts. The complex nature of social value creation can be addressed by using design more extensively in a company, as design is considered to have a more influential place in businesses beyond merely superficial PSB development. It can therefore be used to enhance the PSB elements, which were identified in this research, including (i) reaching the masses, (ii) having a genuine brand story, (iii) understanding culture and context, (iv) encouraging (user) behaviour change, and (v) encouraging system changes. The influence of design in many areas of social value creation also provides a viable option to use design as a strategic tool to create CSR which (i) identifies and analyses the current level, intent and types of CSR activities, (ii) provides a holistic view of a company's activities and (iii) can be used to either intensify CSR effort or diversify social initiatives and can be easily and effectively applied. This research would therefore benefit from further studies of practical design involvement in a company's CSR practices, the output of the creation of the company's social value and the social impact of design, considering how to (i) create and/or deliver social values through design, (ii) strategically use design to improve the social impact of CSR and (iii) objectively measure social benefits of design outputs.

\section{References}

Best, K. (2015) Design Management: Managing Design Strategy, Process and Implementation, 2nd ed. London, Bloomsbury Publishing.

Brown, T. (2009) Change by Design: How Design Thinking Transforms Organisations and Inspires Innovation, NY, HarperCollins.

Bryman, A. (2016) Social Research Methods, 5th ed. Oxford, Oxford University Press 
CED (1971) Social Responsibilities of Business Corporations, Committee for Economic Development. The Committee for Economic Development.

Chen, D. -S., Cheng, L. -L., Hummels, C., \& Koskinen, I. (2015). Social design: An introduction. International Journal of Design, 10(1), 1-5.

Collings, R. (2010) Corporate Social Responsibility. London, The Design Council.

Cook, N. (2011) The social brand value of the world's leading brands [Online]. Sociagility.

Available: http://www.sociagility.com/2011/12/social-brand-value-infographic/

[Accessed 9th March 2016].

DC (2014) Leading Business by Design: Why and how business leaders invest in design.

London, Warwick Business School and The Design Council.

Elkington, J. (2004) 'Enter the Triple Bottom Line', in Henriques, A. \& Richardson. (Eds.), The triple bottom line, does it all add up?: assessing the sustainability of business and CSR. London, Earthscan, pp.1-16.

Esslinger, H. (2009) A Fine Line: How design Strategies are Shaping the Future of Businesses, CA, Jossey-Bass.

EY (2013) 2013 Six growing trends in corporate sustainability. Ernst and Young.

Frolova, I. \& Lapina, I. (2014) Corporate social responsibility in the framework of quality management. Procedia - Social and Behavioral Sciences, 156, 178-182.

Gates, B. (2008) Transcript of Bill Gates - 2008 World Economic Forum - Creative Capitalism, Bill and Melinda Gates Foundation [Online]. World Economic Forum. Available: http://www.gatesfoundation.org/mediacenter/speeches/2008/01/bill-gates-2008world-economic-forum [Accessed 7th September 2016].

Hazarika, A. (2013) Corporate Social Responsibility and Workplace Democracy: Emerging Issues and Perspectives, Journal of Management \& Public Policy, 5 (1), 27-40

Hebbar, M. (2010) Social Entrepreneur - Definition [Online]. Available: http://mhebbar.com/tag/social-entrepreneurship/ [Accessed 9th March 2016].

Hilton, S. (2003) The Social Value of Brand. In: CLIFTON, R. \& SIMMONS, J. (eds.) Brands and Branding. New Jersey: Bloomberg Press.

Hunter, M. (2014) Social enterprise is good for design [Online]. Design Council. Available: http://www.designcouncil.org.uk/news-opinion/social-enterprise-good-design [Accessed 9th March 2014]. 
International Organization for Standardization. (2010) Guidance on social responsibility (ISO Standard No. 26000:2010). Available: https://www.iso.org/standard/42546.html [Accessed 9th December 2017].

Janzer, C. L. \& Weinstein, L. S. (2014) Social Design and Neocolonialism. Design and Culture, 6, 327-343.

Jelsma, J. (2006) Designing 'moralized' products. In: VERBEEK, P.-P. \& SLOB, A. (eds.) User Behavior and Technology Development: Shaping Sustainable Relations Between Consumers and Technology, Dordrecht, Springer Netherlands.

Joziasse, F. \& Selders, T. (2009) The Next Phase: Laying Bare the Contributions of Design. Design Management Review, 20, 28-36.

Koo, Y. \& Cooper, R. (2011) Managing Corporate Social Responsibility Through Design. Design Management Review, 22, 68-79.

Kotler, P. \& Lee, N. (2005) Corporate Social Responsibility: Doing the Most Good for Your Company and Your Cause, New Jersey, John Wiley and Sons.

Lockwood, T. (2011) A study on the value and applications of integrated design management. In: COOPER, R., JUNGINGER, S. \& LOCKWOOD, T. (eds.) The Handbook of Design Management. Oxford: BERG.

Martin, R. (2009) The Design of Business: Why Design Thinking is the Next Competitive Advantage, Boston, Harvard Business Press.

Matten, D. \& Moon, J. (2008) Implicit and Explicit CSR: A Conceptual Framework for a Comparative Understanding of Corporate Social Responsibility. Academy of Management Review, 33, 404-424.

McElroy, M. W. (2002). Social innovation capital. Journal of Intellectual Capital, 3, 30-39.

Moura-Leite, R. C. \& Padgett, R. C. (2011) Historical background of corporate social responsibility. Social Responsibility Journal, 7(4): 528-539.

Mozota, B. B. D. (2006) The Four Powers of Design: A Value Model in Design Management. Design Management Review, 17, 44-53.

Na, J., Choi, Y. \& Harrison, D. (2017) The Design Innovation Spectrum: An Overview of Design Influences on Innovation for Manufacturing Companies. International Journal of Design, 11(2): 13-24.

NIELSEN (2014) Global Consumers are Willing to Put Their Money Where Their Heart is When it Comes to Goods and Services from Companies Committed to Social Responsibility [Online]. Nielsen. Available: http://www.nielsen.com/us/en/press- 
room/2014/global-consumers-are-willing-to-put-their-money-where-their-heartis.html [Accessed 30th June 2014].

Paananen, A. \& Seppänen, M. (2013) Reviewing customer value literature: Comparing and contrasting customer values perspectives. Intangible Capital, 9(3), 708-729.

Papanek, V. (1985) Design for the Real World: Human ecology and social change, 2nd ed. London, Thames \& Hudson.

Piscicelli, L., Cooper, T. \& Fisher, T. (2015) The Role of Values in Collaborative Consumption: Insights from a Product-Service System for Lending and Borrowing in the UK, Journal of Cleaner Production 97 (2015): 21-29.

Polonsky, M. J. \& Jevons, C. (2006) Understanding issue complexity when building a socially responsible brand, European Business Review, 18 (5): 340-349.

Potter, M. E. \& Kramer, M. R. (2006) Strategy and Society: The Link Between Competitive Advantage and Corporate Social Responsibility, Harvard Business Review, 84 (12): 78-92.

PWC (2002) 2002 Sustainability Survey Report. PWC.

Rare Corporate Design (2011) A short guide to Corporate Responsibility Reporting. London, Rare Corporate Design Limited.

Scott, K., Bakker, C., \& Quist, J. (2012). Designing change by living change. Design Studies, $33,279-297$.

Stevens, J. \& Moultrie, J. (2011) Aligning Strategy and Design Perspectives: A Framework of Design's Strategic Contributions. The Design Journal, 14, 475-500.

Sweeney, J. C. \& Soutar, G. N. (2001) Consumer perceived value: The development of a multiple item scale. Journal of Retailing, 77, 203-220.

World Economic Forum. (2016) Social Innovation: A Guide to Achieving Corporate and Societal Value [Online]. World Economic Forum. Available: http://www3.weforum.org/docs/WEF_Social_Innovation_Guide.pdf

Zeithaml, V. A. (1988) Consumer Perceptions of Price, Quality, and Value: A Means-End Model and Sythesis of Evidence. Journal of Marketing, 52, 2-22. 


\section{Figures and Tables}

Figure 1 Theoretical CSR levels for companies (Adapted from CED, 1971)

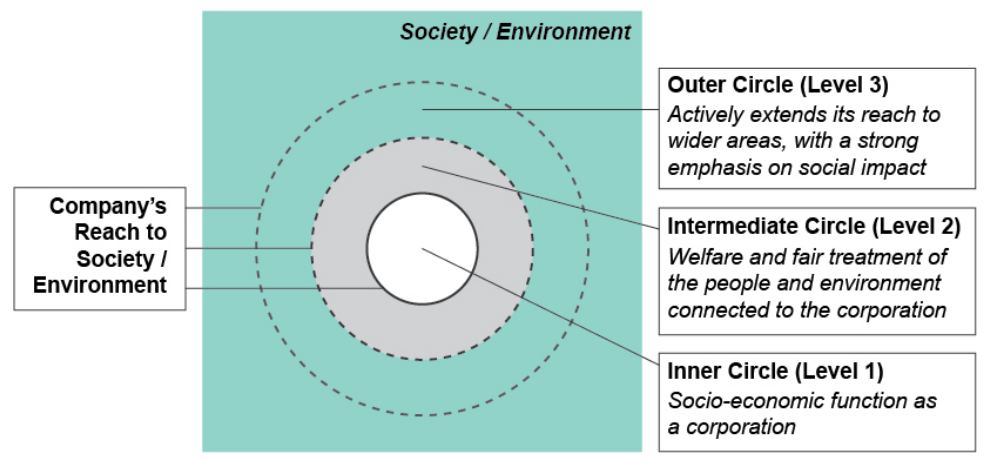

Figure 2 Overview of the relationship between design stakeholders (including social \& commercial design) and examples of products/services with social value.

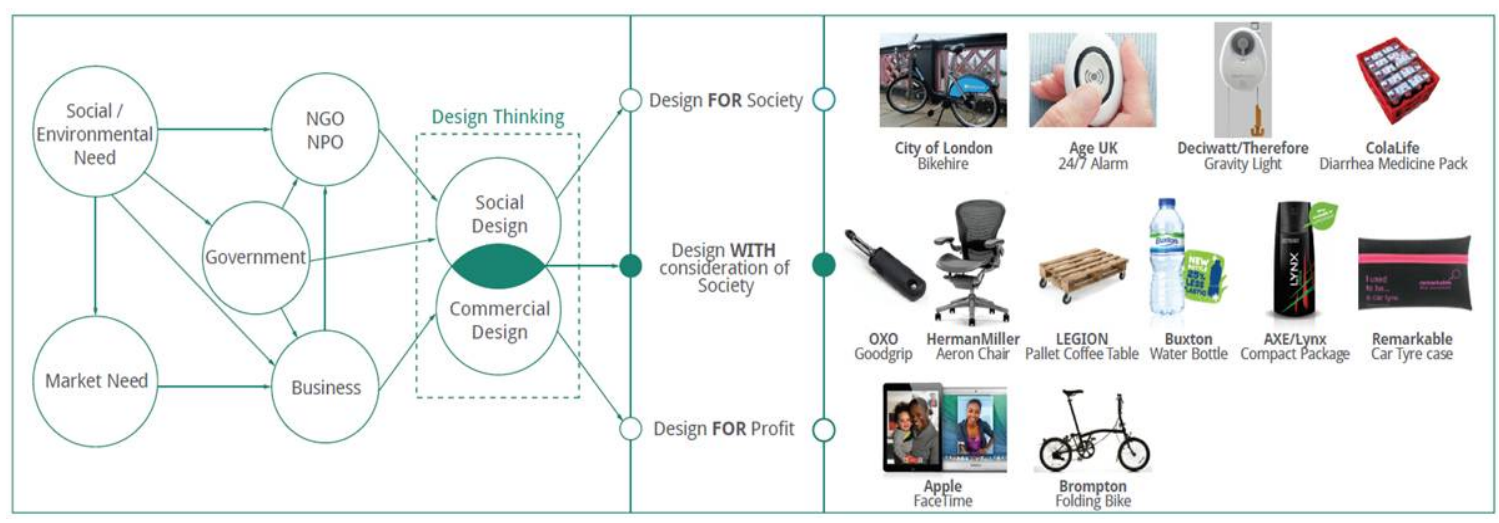

Figure 3 Social Value Matrix with discussion topics and the number of subtopics (in brackets) from exploratory Workshop One.

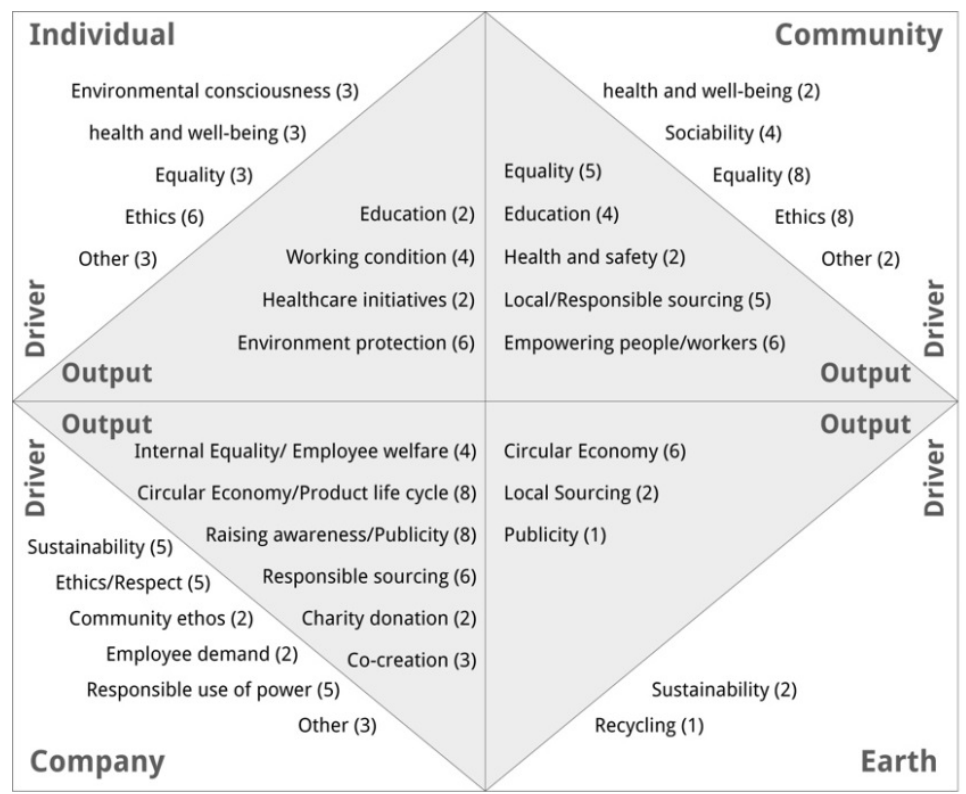


Figure 4 Grouping Product example cards (left), Product/Service System example cards (centre), and Campaign/Brand Promotion example cards (right) on a matrix to determine the relationship between design and social value.
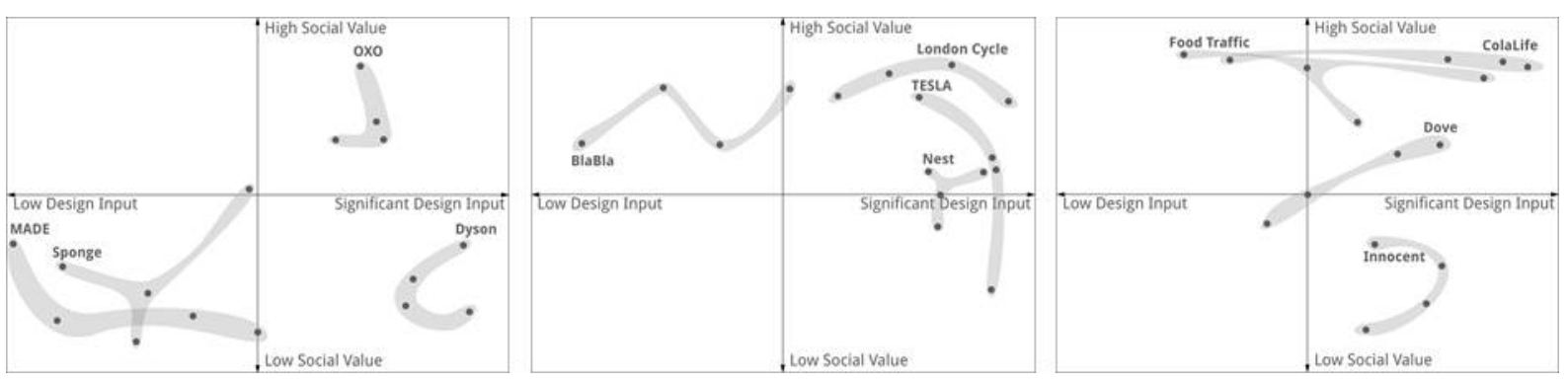

Figure 5 PSB Elements (Actions) which create high social value

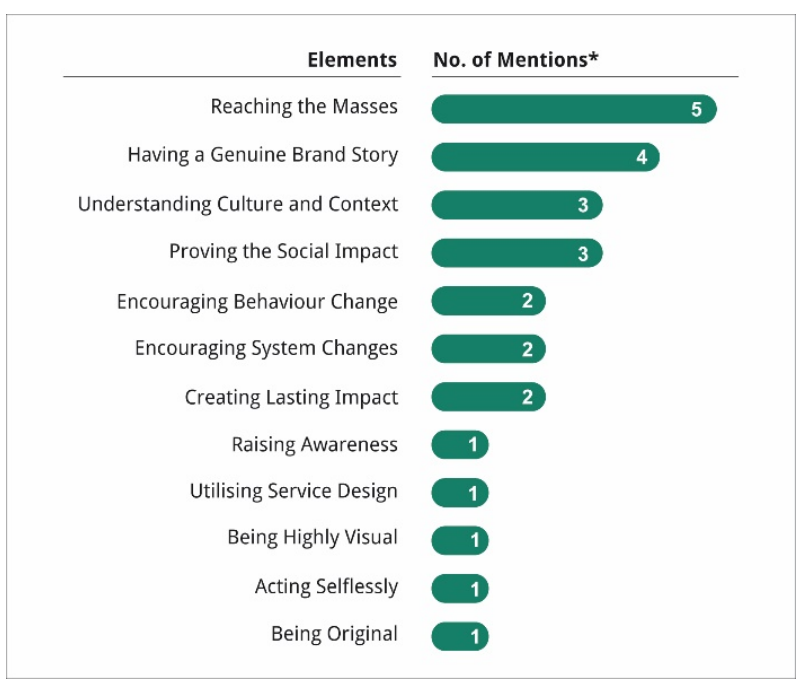

* The number of mentions is an aggregation of the theme identified during the workshop discussion.

Table 1 Current CSR, Brand and Consumer purchasing behaviour issues identified in Workshop One.

\begin{tabular}{ll}
\hline Discussed Issues & Descriptions \\
\hline $\begin{array}{l}\text { The rising value of social } \\
\text { issues }\end{array}$ & Social values are rising in the hierarchy of purchasing decisions. \\
\hline $\begin{array}{l}\text { Sophisticated purchase } \\
\text { decision-making }\end{array}$ & $\begin{array}{l}\text { Now we have a generation of young, brand-savvy shoppers who make } \\
\text { sophisticated decisions - different measures (decision-making perspectives) } \\
\text { for different product/service categories. }\end{array}$ \\
\hline Rise of customer needs & \begin{tabular}{l} 
Is decision-making through social value a luxury for some people? \\
\hline Diverse views
\end{tabular} \\
$\begin{array}{l}\text { In a given society, there will be a spectrum of views on social dimensions, but } \\
\text { we have insufficient knowledge of this spectrum, making it wrong to state that } \\
\text { 'all of the UK population thinks like this'. }\end{array}$
\end{tabular}




\begin{tabular}{ll}
\hline Good and bad for Ryan Air & $\begin{array}{l}\text { Bad - because Ryan Air is seen as making money by tricking customers - i.e. } \\
\text { constant adverts to buy a burger, paying extra for luggage with allowances } \\
\text { seen to be smaller than on other airlines. Good - because it is customers' } \\
\text { responsibility to read the small print if they want a low-price ticket. }\end{array}$ \\
\hline $\begin{array}{l}\text { Complicated shopping } \\
\text { decisions }\end{array}$ & $\begin{array}{l}\text { More complicated than just 'cost' or 'brand'. Group members were interested } \\
\text { in 'quality' - a hybrid of 'vfm' (value for money) and 'brands', because } \\
\text { 'brands' also include the perception of quality. }\end{array}$ \\
\hline $\begin{array}{l}\text { Betrayal of 'eco' personal } \\
\text { care products }\end{array}$ & $\begin{array}{l}\text { It was surprising to see how much we spend on 'eco' products, which are } \\
\text { essentially 'bad' chemicals to spray around ourselves to achieve certain aims. } \\
\text { Perhaps the ethical consideration should be about buying these chemicals. }\end{array}$ \\
\hline $\begin{array}{l}\text { Conformity to the 'social } \\
\text { norm' }\end{array}$ & $\begin{array}{l}\text { Sometimes we ignore this because of conformity - being seen to be within the } \\
\text { 'social norm'. Our social choices occur at a level below that. An 'entry level' } \\
\text { satisfies the 'social norm' i.e. not wanting to smell bad, not wanting to have } \\
\text { greasy hair etc., }\end{array}$ \\
\hline $\begin{array}{l}\text { Criteria vs. consideration } \\
\text { pressure }\end{array}$ & $\begin{array}{l}\text { Is social value the top criteria when making purchasing decisions, or is it only } \\
\text { a consideration? }\end{array}$ \\
\hline Oonvenience vs. social value & $\begin{array}{l}\text { e.g. airlines - local vs. more distant airports, but with social responsibility; } \\
\text { situation dependent. }\end{array}$ \\
\hline $\begin{array}{l}\text { Functionality vs. social } \\
\text { value }\end{array}$ & $\begin{array}{l}\text { Different categories have different criteria - some are practical (functionality) } \\
\text { e.g. household cleaner needs to be effective before considering social value. }\end{array}$ \\
\hline Purchase Frequency & $\begin{array}{l}\text { Frequency of personal interactions and purchase is important: as people } \\
\text { interact more with the product, they think more about social value more e.g. } \\
\text { tea/coffee/water. }\end{array}$ \\
\hline $\begin{array}{l}\text { Commitment to buying socially responsible products or taking on a service to } \\
\text { 'show off' that you care OR to be part of a group of people. }\end{array}$ \\
\hline $\begin{array}{l}\text { Product owned (i.e. household products) vs. not owned (hotel etc). People care } \\
\text { more about the social value of what they 'own' compared with things they do } \\
\text { not own. }\end{array}$ \\
\hline
\end{tabular}

